JOURNAL

of Health Inequalities

\title{
The Polish Anti-tobacco Law - 20 years on
}

\author{
Witold A. Zatoński \\ Health Promotion Foundation, Nadarzyn, Poland \\ Maria Skłodowska-Curie Memorial Cancer Center and Institute of Oncology, Warsaw, Poland
}

KEY WORDS: smoking, tobacco control, health history, tobacco laws.

ADDRESS FOR CORRESPONDENCE: Prof. Witold A. Zatoński, Health Promotion Foundation, 51 Mszczonowska St., 05-830 Nadarzyn, Poland, phone: +48 2273976 40, e-mail: wazatonski@promocjazdrowia.pl

Tobacco smoking is by far the most important preventable factor damaging the health and leading to premature mortality of adults in Europe [1]. May 2016 marked the $20^{\text {th }}$ anniversary of the implementation of Poland's first comprehensive anti-tobacco bill (Fig. 1) [2]. As part of the celebrations, the Polish Health Promotion Foundation and WHO Collaborative Centre at the Maria Skłodowska-Curie Memorial Cancer Centre and Institute of Oncology, in collaboration with the Polish Ministry of Health and the Chief Sanitary Inspectorate, have organised a witness conference ${ }^{1}$, and witness seminar ${ }^{2}$, discussing this important public health development.

The purpose of these events was to document the history of tobacco control in Poland, evaluate the effectiveness of existing legislative measures, and begin work on a roadmap for the next decade of Poland's anti-tobacco efforts. In this issue of the Journal of Health Inequalities we would like to present a series of articles on tobacco control in Poland and in Europe, including an outline of the history of the anti-tobacco movement in Poland, an overview of the significance and impact of the Polish anti-tobacco legislation of 1996, an examination of the recent Polish opposition to the EU Tobacco Products Directive, a policy recommendation paper on tobacco control measures in the Russian Federation, as well as an analysis of trends in smoking among youth in Poland and Norway. In future issues we will present the witness testimonials of key actors and experts involved in health advocacy in Poland which were collected during May's conference and seminar.
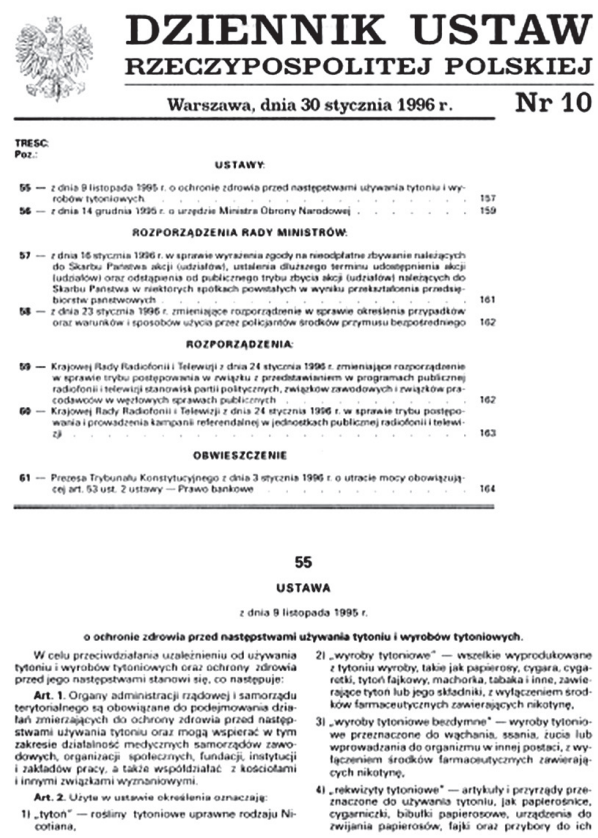

FIG. 1. First Polish comprehensive anti-tobacco bill

\section{DISCLOSURE}

Author reports no conflict of interest.

\section{References}

1. Zatoński W and the HEM project team. Closing the health gap in European Union. Cancer Center and Institute, Warsaw 2008.

2. Dz. U. 1996 nr 10, poz. 55 [Journal of Laws of the Republic of Poland, 1996, no. 10, pos. 55].

The Conference on a Smoke-free Poland was hosted by the Polish Health Minister Dr Konstanty Radziwiłł on 18 May 2016 in the Column Hall of the Ministry of Health, Miodowa 15 St., Warsaw.

${ }^{2}$ The Witness Seminar on the $20^{\text {th }}$ anniversary of the Polish Anti-tobacco Law was held on 31 May 2016 in the Chief Sanitary Inspectorate, Targowa 65 St., Warsaw. 